\title{
PERAN TARI DALAM PERSPEKTIF GENDER DAN BUDAYA
}

\author{
Ayu Vinlandari* \\ IAIN Syekh Nurjati Cirebon \\ Indra Gunawan ${ }^{2}$ \\ IAIN Syekh Nurjati Cirebon
}

email: ayuvinlandari@syekhnurjati.ac.id

email: $\underline{\text { indra16gun@syekhnurjati.ac.id }}$

\section{- Received: 18 Oktober •Accepted: 26 November $\bullet$ Published online:1 Desember 2020 \\ 2020 2020}

\begin{abstract}
:
Tulisan ini bertujuan untuk mengungkapkan dan menjelaskan bagaimana peranan tari dalam perspektif gender dan budaya. Tulisan ini berangkat dari sebuah permasalahan yakni masih adanya pandangan stereotype gender tentang tari dalam pandangan masyarakat sosial. Pemahaman mengenai tari dalam sudut pandang masyarakat sosial masih menimbulkan pro dan kontra. Hal tersebut dikarenakan masih kurangnya rasa ingin tahu serta pemahaman terhadap tari itu sendiri, sehingga masih banyak yang menganggap bahwa tari hanya dapat ditarikan oleh wanita saja. Tari merupakan sebuah gejolak ekspresi manusia yang dituangkan ke dalam gerak ritmis yang indah, yang dapat ditarikan baik oleh laki-laki maupun perempuan. Dalam sebuah tarian memiliki tujuan dan fungsinya masingmasing. Penelitian ini menggunakan pendekatan kualitatif dengan metode penelitian studi literatur. Analisis data menggunakan metode deskriptif analisis dengan tujuan untuk mendapatkan sebuah analisis dari permasalahan yang diusung. Penelitian ini menghasilkan sebuah analisis yakni tarian adalah suatu kegiatan yang dilakukan dengan tidak memandang gender.
\end{abstract}

Kata kunci: tari, gender, budaya

\begin{abstract}
This paper aims to reveal and explain the role of dance in a gender and cultural perspective. This paper departs from a problem, namely there is still a gender stereotype view of dance in the view of social society. The understanding of dance from the point of view of social society still raises pros and cons. This is because there is still a lack of curiosity and understanding of dance itself, so there are still many who think that dance can only be danced by women. Dance is a turmoil of human expression that is poured into beautiful rhythmic movements, which can be danced by both men and women. In a dance has its own purpose and function. This study used a qualitative approach with a literature study research method. Data analysis used descriptive analysis method with the aim of obtaining an analysis of the problems being carried. This research produces an analysis, namely dance is an activity that is carried out regardless of gender.
\end{abstract}

Keywords: dance, gender, culture

${ }^{*}$ Corresponding Author, Email: ayuvinlandari@syekhnurjati.ac.id 


\section{A. PENDAHULUAN}

Tari, gender, dan budaya merupakan ketiga hal yang tidak dapat dipisahkan. Berbicara mengenai tari, gender, dan budaya maka terdapat beberapa keterkaitan, seperti tari dalam budaya, tari dalam gender, dan gender dalam budaya. Budaya merupakan identitas sebuah bangsa, tari merupakan sebuah alat yang berkaitan dengan budaya dan kesenian, dan gender adalah sesuatu yang sering kita dijumpai pada kehidupan sehari-hari, dan gender merupakan sesuatu yang berkaitan dengan jenis kelamin, namun gender di sini bukan berorientasi pada perbedaan jenis kelamin, melainkan berorientasi pada perilaku berdasarkan jenis kelaminnya. Budaya merupakan pengikat suatu bangsa, budaya merupakan identitas sosial. Banyak hal yang berhubungan dengan budaya, seperti halnya cara duduk dan cara jalan seseorang dipengaruhi oleh budayanya masing-masing. Budaya lebih memfokuskan kepada kebiasaan yang dilakukan akibat dari pengaruh lingkungan serta pola pikir masyakarat suatu tempat atau suatu daerah.

Berbicara mengenai tari dalam perspektif budaya, tari merupakan sebuah bagian yang terdapat dalam budaya, karena tari merupakan symbol atau identitas dari sebuah kelompok sosial, kota, provinsi, bahkan negara. Namun, terdapat hal yang disayangkan, berdasarkan fenomena sosial masih ada anggapan bahwa seorang wanita yang melakukan tari dipandang sebelah mata, bahkan menimbulkan sebuah pelecehan. Sejatinya, sebuah tari tentu memiliki tujuan dan fungsinya masing-masing, namun pandangan masyarakat sosial yang perlu diluruskan dalam memaknai sebuah tari ataupun pertunjukkan tari. Tari merupakan sebuah simbol budaya, karena menurut budaya dalam arti luas adalah bentuk budaya fisik yang memiliki gaya tertentu dan menghasilkan sebuah tarian. Menari merupakan sebuah komunikasi yang berasal dari kehidupan, dan tari digambarkan sebagai stiliasi kualitas gerakan sehari-hari. Gaya tarian mencerminkan budaya yang berasal dari masyarakatnya masing-masing. Gaya tari merupakan ekspresi alami dari sistem budaya dan juga merupakan metafisik budaya.

Hal lain yang berkaitan pula dengan budaya dan tari yakni gender. Banyak perspektif mengenai budaya dan gender, seperti halnya ada perspektif yang menyatakan bahwa pria bekerja sebagai pencari nafkah dan wanita bekerja 
mengurusi rumah tangga dan mengurusi anak. (Sarwono, 2013) mengatakan mengenai peran gender antara pria dan wanita, bahwa:

“Peran gender yaitu sampai di mana seseorang mengadopsi perilaku spesifik gender yang digariskan oleh kebudayaannya. Misalnya, sampai di mana seorang wanita mengambil peran mengasuh dan mendidik anak, dan seorang laki-laki adalah mencari nafkah untuk keluarganya".

Berdasarkan pendapat di atas, maka gender merupakan perilaku seseorang yang dipandang dari segi kebudayaannya masing-masing. Namun, pada kenyataannya, tidak semua peran wanita dilakukan oleh wanita saja, dan begitupun sebaliknya, tidak semua peran pria dilakukan oleh pria saja. Ada kalanya peran pria dilakukan oleh wanita, dan ada pula peran wanita yang dilakukan oleh pria. Perilaku berdasarkan peran gender tersebut tergantung bagaiman cara pandang kita, dan tentunya perilaku yang berdasarkan peran gender tersebut memiliki tujuannya masing-masing.

Perilaku yang mayoritas sering dilakukan oleh kaum wanita yaitu menari. Menari identik dengan wanita dan tata rias (make-up), maka apabila ada pria yang menari, terkadang selalu dipandang sebelah mata. Namun, ternyata menari tidak hanya dilakukan oleh kaum wanita, banyak kaum pria yang tentunya mengikuti kegiatan menari, seperti halnya sebuah pergelaran drama tari. Pergelaran drama tari tidak selalu melibatkan wanita di dalamnya, namun banyak pria yang memiliki peran tertentu dalam pergelaran drama tari tersebut. Pandangan gender dalam tari disesuaikan dengan peran gender masing-masing individu dari budayanya masingmasing. Karakter dan gaya tarian laki-laki didasarkan dari peran mereka dalam kebudayaan. Begitu pun dengan karakter dan gaya tari perempuan, yang juga didasarkan dari peran perempuan dalam budayanya. Dilihat dari suku budaya, memang terdapat perbedaan antara tarian perempuan dan laki-laki, sehingga pandangan mengenai tarian hanya dilakukan oleh wanita saja dapat dibuktikan dan dilihat dari gaya tariannya. Dengan demikian, tari, budaya, dan gender bagaikan sebuah siklus yang berputar tiada henti, karena ketiga hal tersebut saling mengikat dan juga saling mempengaruhi. Jelaslah bahwa tari dan budaya tersebut dapat menunjukkan sebuah perbedaan berdasarkan spesifik gender. 


\section{B. METODOLOGI PENELITIAN}

Penelitian ini menggunakan pendekatan kualitatif dengan metode studi literatur. Menurut (Moleong, 2014) penelitian kualitatif adalah penelitian yang bermaksud untukmemahami fenomena tentang apa yang dialami oleh subjek penelitian misalnya perilaku, perspesi, motivasi, tindakan, dll, secara holistic, dan dengan cara deskripsi dalam bentuk kata-kata dan Bahasa, pada suatu konteks khusus yang alamiah dan dengan memanfaatkan berbagaimetode alamiah. Metode penelitian studi literatur digunakan dengan mencari referensi yang relevan terkait dengan permasalahan yang diusung. Teknik pengumpulan data yaitu dengan mengumpulkan data primer dan sekunder. Data primer diperoleh dengan melakukan observasi terhadap kelompok masyarakat mengenai permasalahan dalam penelitian ini. Data sekunder diperoleh dari jurnal dan buku yang relevan dengan permasalahan. Teknik analisis data dalam penelitian ini yakni melalui analisis dengan menggunakan metode deskriptif analisis. (Creswell, 2016) mengatakan bahwa analisis data dalam penelitian kualitatif akan berlangsung bersamaan dengan bagian-bagian lain dari pengembangan penelitian kualitatif, yaitu pengumpulan data dan penulisan temuan. Metode deskriptif analisis dilakukan dengan mendeskripsikan fakta-fakta yang selanjutnya diperlukan sebuah analisis. Analisis yang digunakan bertujuan untuk memberikan pemahaman serta penjelasan terhadap permasalahan yang diusung.

\section{RESULT AND DISCUSSION}

Tari, gender, dan budaya merupakan satu hal yang sama dan memiliki keterkaitan satu sama lainnya. Tari merupakan gejolak ekspresi manusia yang dituangkan melalui gerakan ritmis yang memiliki nilai estetis. Khutniah \& Eny Iryanti (2012) mengatakan tari merupakan kegiatan kreatif dan konstruktif yang dapat menimbulkan intensitas emosional dan makna. Tari memiliki potensi untuk mengungkapkan perasaan, hal tersebut sebagai bentuk luapan emosional dari penarinya, karena dalam tari terdapat unsur wirasa yang berkaitan dengan penjiwaan dan perasaan. Tari tidak akan lepas dari peranan gender, karena untuk 
beberapa orang tari dijadikan sebagai mata pencahariannya. Gender merupakan pandangan terhadap sifat seseorang yang disesuaikan menurut jenis kelaminnya. Hermawati (2007) mengatakan bahwa Gender adalah semua atribut sosial mengenai laki-laki dan perempuan, misalnya laki-laki digambarkan mempunyai sifat maskulin seperti keras, kuat, rasional, gagah. Sementara perempuan digambarkan memiliki sifat feminin seperti halus, lemah, perasa, sopan, penakut. Perbedaan tersebut dipelajari dari keluarga, teman, tokoh masyarakat, lembaga keagamaan dan kebudayaan, sekolah, tempat kerja, periklanan dan media. Dengan demikian, gender berkaitan dengan kehidupan, yakni pada awalnya cara hidup hanya dapat dialami dari perspektif satu jenis kelamin tertentu, namun dengan adanya budaya, maka cara pandang mengenai gender harus mencakup tentang kedua jenis kelamin yang berbeda, yakni budaya laki-laki dan budaya perempuan. Dalam gender terdapat pembagian peran antara laki-laki dan perempuan secara sosial budaya dan secara kodrati. Gender dalam perspektif budaya dapat berubah dan dipertukarkan antara laki-laki dan perempuan. Gender dalam perspektif kodrati yakni seperti perempuan yang secara fitrahnya mengalami haid, hamil, melahirkan, dan menyusui. Istilah gender mengacu pada makna sosial, budaya, dan biologis. Peran gender bisa berubah karena dipengaruhi oleh ideologi, ekonomi, adat, agama, dan sosial budaya, etnik, waktu, tempat, dan kemajuan iptek (Putraningsih, 2000).

Selanjutnya tari pun tidak akan lepas dari budaya, karena tari mengandung nilai-nilai sosial dan budaya, bahkan pada dasarnya kehidupan pun tidak pernah luput dari peranan budaya. Budaya adalah sebuah landasan dalam melangsungkan kehidupan setiap individu. Budaya merupakan sebuah alat pengikat yang menjadi pedoman dalam kehidupan masyarakat, sedangkan budaya menurut antrolpologi merupakan segala sesuatu yang berasal dari kelompok sosial yang memiliki kesamaan. Koentjaraningrat (2011) mengatakan bahwa budaya menurut antropologi adalah seluruh sistem gagasan dan rasa, tindakan, serta karya yang dihasilkan manusia dalam kehidupan bermasyarakat, yang dijadikan miliknya dengan belajar. Berdasarkan pendapat Koentjaraningrat tersebut, maka seluruh tindakan atau perilaku manusia dalam kehidupannya disebut dengan kebudayaan. Selanjutnya Koentjaraningrat (2011) menyatakan bahwa: 
"Hampir semua tindakan manusia adalah "kebudayaan", karena jumlah tindakan yang dilakukannya dalam kehidupan bermasyarakat yang tidak dibiasakannya dengan belajar (yaitu tindakan naluri, refleks, atau tindakan-tindakan yang dilakukan akibat suatu proses fisiologi, maupun berbagai tindakan membabibuta), sangat terbatas. Bahkan berbagai tindakan yang banyak dirombak oleh manusia sendiri sehingga menjadi tindakan kebudayaan".

Manusia merupakan makhluk sosial dan makhluk individual. Manusia terlahir dengan bentuk fisik, memiliki akal, dan perasaan, dengan demikian manusia mampu bertindak, berpikir, dan merasakan apapun yang terjadi. Sujarwa (2014) mengatakan bahwa manusia sebagai makhluk individu memiliki unsur jasmani dan rohani; unsur fisik dan psikis; unsur jiwa dan raga. Dari mulai lahir, seorang individu memiliki hak dalam menggunakan tubuh atau fisiknya, yang dimana hal tersebut berhubungan dengan unsur fisiologis dan fenomena biologis. Dalam konteks budaya, pembangunan fisik seperti berdiri, berjalan, dan pertahanan tubuh dapat berbeda dari masyarakat budaya satu dengan masyarakat budaya lainnya. Namun, perilaku seperti cara duduk, cara berjalan, dan cara tidur tersebut dipandang sebagai cara alami dari tubuh dalam berperilaku. Pemahaman tubuh manusia terdiri dari dua, yakni tubuh secara fisik dan juga tubuh secara sosial dalam masyarakat. Baik tubuh secara fisik, maupun tubuh sosial harus menghasilkan sebuah harmoni atau keselarasan. Keterkaitan antara tubuh secara fisik dan tubuh sosial yakni tubuh sosial merupakan refleksi dari pengalaman lintas budaya yang berasal dari kecenderungan fisiologis.

Polhemus (1993) mengatakan bahwa :

"Indeed, anthropology itself has traditionally been divided between, on the one hand physical anthropology which deals with the evolutions of the human body and, on the other hand, social or cultural anthropology which deals with human social organization and its products and artefacts".

Hal tersebut dapat dimaknai bahwa tubuh manusia dalam antropologi tradisional yakni terbagi menjadi dua, yaitu satu sisi antropologi fisik yang berkaitan dengan evolusi tubuh manusia, dan sisi lain yaitu antropologi sosial dan budaya yang berkaitan dengan organisasi sosial manusia. Antropologi fisik mempelajari mengenai bentuk tubuh manusia yang berkaitan dengan evolusi. Tentu saja kita mengenal tentang evolusi, yang dimana terdapat sebuah teori yang membahas mengenai proses terjadinya manusia, yaitu Teori Evolusi yang dicetuskan oleh Darwin. Arons (2007) menyatakan bahwa:

"Some evolutionary theories date the biped upright posture to a human ancestor called Toumai, as far back as 7 million years ago. Nearer to our times and present human 
form, science tells us that homo habilus, found at the boundary between early and modern humans, prospered between 2.3 and 1.3 million years ago, marked by an increasingly upright stance, use of tools, and more cooperative living. There was also a remarkable increase in brain size. Homo habilus was followed by homo erectus (upright human) with further and marked increase in brain size-before either organized society or the advent of language (Ornstein, 1991). Despite the evolving distinctions between human and ape, recent DNA evidence draws a close genetic relationship between them, notably with the chimpanzee".

Berdasarkan pendapat Arons di atas, dapat ditarik kesimpulan bahwa dalam teori evolusi, manusia memiliki kesamaan DNA dengan makhluk primata atau yang disebut simpanse dan manusia memiliki sifat kreatif yang berasal dari spesies tertua yaitu yang memiliki dua kaki serta bertubuh tegak. Selanjutnya Koentjaraningrat (2011) menegaskan bahwa manusia adalah suatu jenis makhluk Primat yang telah bercabang melalui proses evolusi. Dalam teori tersebut dijelaskan mengenai asalusul manusia yang memiliki tubuh tegak dan disebutkan pula mengenai Homo Erectus (manusia tegak), homo erectus berkaitan dengan asal-usul manusia, atau bagaimana awal manusia muncul. Setelah diketahui mengenai tubuh manusia yang tegak, kemudian ditandai dengan peningkatan ukuran otak manusia. Peningkatan ukuran otak manusia dimaksudkan agar manusia memiliki kulitas berpikir yang lebih dibandingkan makhluk lainnya. Penjelasan tersebut dipertegas melalui pernyataan Goleman (2015) yang menyatakan bahwa:

"Kodrat manusia muncul dari arsitektur dasar kehidupan mental. Dari segi bentukan biologis jaringan sirkuit saraf dasar emosi, sifat-sifat bawaan adalah apa yang paling berhasil berfungsi selama 50.000 generasi manusia yang terakhir, bukan 500 generasi dan pasti bukan lima generasi terakhir. Kemampuan evolusi yang lambat dan hati-hati yang telah membentuk emosi telah berjalan dengan baik selama sejuta tahun".

Berdasarkan pernyataan tersebut, maka manusia tumbuh dan berkembang bukan hanya dari faktor biologisnya saja, tetapi juga faktor psikologisnya, seperti emosi. Goleman (2015) menegaskan bahwa otak manusia dengan berat kurang lebih satu setengah kilogram yang terdiri atas sel-sel cairan saraf, kurang lebih berukuran tiga kali ukuran otak kerabat-kerabat paling dekat dengan kita dalam evolusi, yaitu primata bukan manusia. Dengan demikian, manusia memiliki perbedaan dengan primata yaitu manusia memiliki kemampuan yang lebih dibandingkan dengan primata dan ini disebabkan pula oleh ukuran otak manusia yang lebih besar dibandingkan primata.

Selanjutnya Polhemus (1993) menambahkan bahwa :

"Margaret Mead, for example, in her work with Gregory Bateson (1942) and Francis Cooke Macrgegor (1951) has shown not only that the members of traditional Balinese society learn to use their bodies in a style which is radically different from our own, but also that such physical behaviour is an intrinsic and fundamental part of Balinese culture. For Mead and her co-authors the essence of Balinese character is Balinese style comportment".

Berdasarkan pendapat Polhemus di atas, yakni terdapat contoh budaya masyarakat yakni budaya masyarakat Bali. Dalam contoh tersebut ditunjukkan bahwa tidak hanya anggota masyarakat tradisional Bali yang belajar untuk menggunakan tubuh mereka dengan gaya yang berbeda, tetapi juga bahwa perilaku 
fisik merupakan bagian intrisik dan mendasar dari budaya Bali. Aktivitas fisik sangat resisten terhadap perubahan dan juga tidak hanya merupakan komponen penting dari identitas sosial dan budaya. Namun, budaya tidak hanya mencakup dimensi fisik, gaya fisiklah yang menandakan atau mewujudkan makna dari masyarakat tertentu.

Budaya dalam arti luas diwujudkan dalam bentuk budaya fisik yang kemudian disalurkan menjadi bentuk tarian. Namun, hal tersebut tidak berhubungan dengan jenis kelamin, karena budaya laki-laki berbeda dengan budaya perempuan dalam mengungkapkan tarian mereka. Budaya memandang bahwa tarian diidentifikasi dan diwujudkan berdasarkan jenis kelamin tertentu, contohnya apabila pria dan wanita menari bersama, maka akan timbul sebuah pertikaian budaya. Dalam sosio-etis, pria dan wanita menari secara terpisah dan sesuai dengan gaya tarinya masing-masing. Gaya tarian pada pria adalah kristalisasi dari apa yang menjadi peran mereka dalam kebudayaannya. Gaya tarian perempuan adalah kristalisasi dari apa yang menjadi peran perempuan dalam budayanya. Dalam masyarakat suku budaya, memang terdapat perbedaan antara tarian perempuan dan laki-laki.

Polhemus (1993) mengatakan terdapat sebuah teori yang mendukung asumsi mengenai tari dan fisik yakni Choreomatrics. Choreomatrics memiliki definisi mengenai ukuran tari atau tari sebagai sebuah ukuran dari budaya. Choreomatrics menciptakan sistem pengkodean untuk mencetak parameter utama tari (bentuk transisi, bentuk kegiatan, transisi energi, tingkat variasi, dan penyebaran aliran melalui tubuh). Dalam choreomatrics terdapat hubungan intrinsik antara gaya tari dan gaya gerakan sehari-hari. Tari digambarkan sebagai stilisasi kualitas gerakan sehari-hari. Selanjutnya, gaya tarian yang berasal dari masyarakat dan diteliti oleh Proyek Choreomatrics tampaknya mencerminkan budaya dari masyarakat tersebut, artinya bahwa gaya tari bukan hanya sebaga ekspresi dari sistem budaya di mana mereka di temukan. Tari adalah gaya dari budaya fisik para rakyat yang diwujudkan melalui cara yang unik. Tari merupakan metafisik budaya. Hal-hal yang mendukung budaya dalam mengatur struktur cara hidup antara lain pola kekerabatan, etnis, organisasi politik, agama, dan kosmologi. 
Faktor-faktor tersebut berhubungan pula dengan tari, karena tarian adalah sistem penandaan yang memiliki akar yang menembus ke inti budaya. Tarian merupakan bagian dari kesenian, dan tentu saja kesenian selalu beriringan dengan kebudayaan. Subiantoro (2008) menyatakan bahwa seni tari sebagai "media komunikasi estetis" yang mengkomunikasikan gagasan melalui ekspresi seni yang spesifik, pada dasarnya dapat mengkomunikasikan berbagai hal. Tari sebagai ekspresi atau pengungkapan jiwa yang dinyatakan dalam bentuk gerakan ritmis yang indah. Berdasarkan pendapat Subiantoro (2008), maka seni tari dinilai pula sebagai media komunikasi, maka tidak hanya bahasa yang dapat dijadikan sebagai media komunikasi, tari pun dapat dijadikan sebagai media komunikasi. Namun, tari sebagai media komunikasi dapat mewujudkan sebuah estetika atau nilai keindahan. Polhemus mengatakan bahwa tari disalurkan melalui cara yang unik, maka dengan cara yang unik itulah keindahan dapat tercermin dalam seni tari. Caturwati (2008) mengatakan bahwa tari merupakan salah satu media ungkap dan sarana pembentukan citra, kepribadian, serta identitas dari seseorang atau kelompok. Dengan demikian, selain sebagai media komunikasi, tari pun dinilai sebagai media dalam pembentukan karakter individu serta identitas dari seseorang atau kelompok. Berdasarkan pendapat tersebut, maka tari dapat mencerminkan budaya dari masyarakatnya melalui Proyek Choreomatrics.

Tari pun berkenaan dengan gender, yang dimana setiap tarian memiliki gaya tariannya masing-masing disesuaikan dengan gender, yakni gaya tari antara laki-laki dan perempuan berbeda. Namun, dalam proses menari, laki-laki selalu dianggap sebagai pemimpin dan perempuan mengikuti arahan dari laki-laki. Pernyataan tersebut sejalan dengan penelitian yang telah dilakukan oleh Williams dalam (Sarwono, 2013), yakni menunjukkan konsistensi perbedaan peran gender antara laki-laki dan perempuan, yaitu:

"Laki-laki selalu dipandang sebagai makhluk yang aktif, kuat, dan penyelesai masalah seperti yang digambarkan dalam mitos Amerika sebagai Superman dan Spiderman, sedangkan perempuan adalah makhluk yang lemah, pasif, dan perlu dilindungi seperti Louis Lane (pacarnya Superman) dan Gwen Stacey (pacarnya Spiderman)".

Dengan demikian, laki-laki memang selalu dipandang lebih kuat daripada perempuan, dan perempuan dipandang sebagai makhluk yang pasif, lemah, dan mengasihi. Namun, pada kenyataannya, tidak selamanya perempuan memiliki sikap demikian, perempuan harus kuat, aktif, dan dapat melindungi dirinya sendiri. Hal 
yang serupa terjadi pada tari di Indonesia, yakni tari komunal. Dibia (2002) mengatakan bahwa:

"Di banyak daerah kita jumpai tarian komunal yang hanya dibawakan oleh kaum laki-laki. Di Bali, tari baris gede, tari kepahlawanan yang bersifat upacara, hanya ditarikan oleh kaum laki-laki. Dalam tarian ini para penari yang terdiri dari para remaja dan dewasa menari secara massal dengan membawa properti berupa perlengkapan senjata perang (tombak, keris, bedil, dan lain sebagainya)".

Berdasarkan pendapat Dibia tersebut, maka gaya tarian laki-laki memang sesuai dengan apa yang menjadi peran mereka dalam kebudayaan. Selain tari yang hanya ditarikan oleh kaum laki-laki, terdapat pula tarian yang hanya dapat ditarikan oleh kaum perempuan. Dibia menegaskan bahwa selain tarian yang hanya diperbolehkan ditarikan oleh kaum lelaki, di banyak tempat juga dijumpai tarian komunal yang hanya ditarikan kaum perempuan. Selanjutnya Dibia (2002) menyebutkan tentang tarian yang hanya ditarikan oleh kaum perempuan, antara lain:

"Bailao di Sumatera Barat adalah contoh tarian yang dilakukan hanya oleh perempuan. Tari Hudoq, yang khusus untuk perempuan, yang memakai topeng abstrak berupa cadar, juga terdapat pada masyarakat Dayak Kenyah di Kalimantan. Tarian burung enggang di Dayak itu biasanya hanya ditarikan oleh perempuan".

Dengan demikian, sama halnya seperti tarian kaum laki-laki, gaya tarian perempuan pun merupakan kristalisasi dari apa yang menjadi peran perempuan dalam kebudayaan. Dari pernyataan di atas, maka dapat terlihat jelas bahwa baik kaum laki-laki maupun kaum perempuan sudah memiliki porsi nya masing-masing dalam menafsirkan gaya tari, dalam kehidupan sosial pun demikian, baik kaum lakilaki dan kaum perempuan memiliki peranannya masing-masing. Tari merupakan sebuah aktivitas yang dapat dilakukan baikoleh laki-laki maupun perempuan, sehingga gender dalam hal ini menjadi patokan dalammenentukan gaya atau karakter tarian.

\section{CONCLUSION}

Budaya merupakan sebuah pengikat yang berpegang pada kebersamaan para masyarakat. Budaya tidak hanya dimiliki oleh kalangan elit saja. Komponenkomponen budaya di antaranya agama, kosmologi, sistem etnis, dan bahasa. Budaya berkenaan dengan cara hidup individu, cara individu tersebut merupakan refleksi dari sebuah perilaku yang berbeda dari setiap kebudayaan, sehingga perilaku individu disesuaikan pada budaya di mana dia tinggal. Selain budaya, hal lain yang dianggap sebagai identitas sosial yaitu tari. Tari merupakan bentuk identitas sosial dan dalam tari terdapat hubungan intrinsik antara gaya dalam tari sendiri dengan 
gaya dalam kehidupan sehari-hari, teori tersebut yakni choreomatrics. Budaya dan tari dipengaruhi pula oleh gender, karena ketiga hal tersebut merupakan hal yang berkaitan satu sama lainnya. Gender merupakan pemahaman mengenai jenis kelamin yang diaplikasikan dengan perilaku. Terdapat dua budaya yakni budaya laki-laki dan budaya perempuan. Budaya dalam arti luas diwujudkan dalam bentuk budaya fisik yang kemudian disalurkan menjadi bentuk tarian. Budaya memandang bahwa tarian didefinisikan dan diwujudkan berdasarkan jenis kelamin tertentu. Tarian merupakan sesuatu yang dapat dilakukan baik oleh laki-laki maupun perempuan, dengan kata lain yakni tarian adalah sesuatu yang tidak memandang gender. Namun, dalam sebuah tarian disesuaikan dengan gaya dan karakter sebuah gender tersebut. Selanjutnya, fenomena mengenai wanita yang dipandang sebelah mata ketika menari yakni mendapat sebuah kejelasan, bahwasanya sebuah tarian merupakan simbol dari sebuah budaya yang tentunya memiliki tujuan dan fungsinya masing-masing. Sebuah tarian berpaku pada norma dan aturan dalam tatanan nilai agama dan sosial. Namun, masih perlu penegasan kepada para oknum seni khususnya tari agar selalu berpangku pada norma agama dan sosial yang berlaku di masyarakat.

\section{REFERENCES}

Arons, M. (2007). Standing Up For Humanity: Upright Body, Creative Instability, and Spiritual Balance. In R. Richards (Ed.), Everyday Creativity (pp. 175-193). American Psychological Association.

Caturwati, E. (2008). Tari Kariaan. In E. Caturwati \& S. Rustiyanti (Eds.), Tari Anak-anak dan Permasalahnnya (pp. 81-102). Sunan Ambu Press STSI Bandung.

Creswell, J. W. (2016). Research Design (4th ed.). Pustaka Pelajar.

Dibia, I. W., Widaryanto, F., \& Suanda, E. (2002). Tari Komunal. Lembaga Pendidikan Seni Nusantara.

Goleman, D. (2015). Emotional Intelligence (Kecerdasan Emosional) (20th ed.). Gramedia.

Hermawati, T. (2007). Budaya Jawa dan Kesetaraan Gender. Jurnal Komunikasi Massa, 1(1), 18-24. https://doi.org/10.1111/j.1523-1739.2010.01600.x

Khutniah, N., \& Eny Iryanti, V. (2012). Upaya Mempertahankan Eksistensi Tari Kridha Jati Di Sanggar Hayu Budaya Kelurahan Pengkol Jepara. Upaya Mempertahankan Eksistensi Tari Kridha Jati Di Sanggar Hayu Budaya Kelurahan Pengkol Jepara, 1(1), 9-21. https://doi.org/10.15294/jst.v1i1.1804

Koentjaraningrat. (2011). Pengantar Antropologi I (4th ed.). Rineka Cipta.

Moleong, L. J. (2014). Metode Penelitian Kualitatif (33rd ed.). Remaja Rosdakarya.

Polhemus, T. E. D. (1993). Dance, Gender and Culture. Dance, Gender and Culture, 3-4. https://doi.org/10.1007/978-1-349-22747-1

Putraningsih, T. (2000). Sebuah Kajian Perspektif Gender. Imaji, 4(1), 20-31. https://staffnew.uny.ac.id/upload/132061380/penelitian/Jurnal+Tr+Perspektif+gender.pd $\mathrm{f}$

Sarwono, S. W. (2013). Psikologi Lintas Budaya. In ウイルス (2nd ed., Vol. 52, Issue 1). 
Ayu Vinlandari Wahyudi, Indra Gunawan

Raja Grafindo Persada.

Subiantoro, I. H. (2008). Komposisi Tari Laku Kreatif Terhadap Penciptaan Tari Anak. In E.

Caturwati \& S. Rustiyanti (Eds.), Tari Anak-anak dan Permasalahnnya (pp. 35-60). Sunan Ambu Press STSI Bandung.

Sujarwa. (2014). Ilmu Sosial dan Budaya Dasar (3rd ed.). Pustaka Pelajar. 